\title{
The Effect of Combining both Internal and External Cooling Methods on Cyclist, S Performance in Hot and Humid Conditions
}

\author{
Xiaomin $\mathrm{CAI}^{1} \&$ Hao $\mathrm{WU}^{2}$ \\ Capital university of physical education and sports, China
}

\begin{abstract}
Research purposes: in the experiment of simulated high temperature and high humidity environment, by using four methods of precooling (oral ice slurry + ice vest, vest, oral ice slurry 、 control), compare the four methods of precooling under high temperature and high humidity environment impact on the power bicycle sports ability of athletes. Methods: four subjects postprandial $2 \mathrm{~h}$ into the lab, after quiet rest $15 \mathrm{~min}$ start the test of basic value. Then intervene precooling of four subjects in turn, each participant completed the experimental intervention order is the same, the first control group - ice vest - oral ice slurry group - joint precooling group, precooling time is $30 \mathrm{~min}$. after precooling immediately determinate relevant indicators, then immediately into the simulation of high temperature and high wet lab for increasing load of power cycling, the movement began power is $60 \mathrm{~W}$, each $5 \mathrm{~min}$ increase $40 \mathrm{~W}$, until exhausted, every $5 \mathrm{~min}$ acquisition related indexes in the process of movement. The results of the study: 1 in terms of the power cycling test distance, combination of cooling jacketand ice injestion $(\mathrm{J}+\mathrm{V})$, using oral ice slurry precooling $(\mathrm{O})$ measures compared with control group $(\mathrm{C})$, there are significant differences $(\mathrm{p}<0.05)$; Ice vest $(\mathrm{I})$ compared with $\mathrm{C}(\mathrm{p}<0.05)$ there are significant differences; $\mathrm{J}+\mathrm{V}$ precooling compared with $\mathrm{C}$ group, $(\mathrm{p}<$ $0.01)$ has a very significant difference; $\mathrm{J}+\mathrm{V}$ precooling compared with $\mathrm{I}(\mathrm{p}<0.05)$, there is significant difference. 2 before and after oral ice slurry precooling the body's core temperature $(\mathrm{p}<0.01)$ has a very significant difference; Joint precooling group of core body temperature $(\mathrm{p}<0.01)$ has a very significant difference; Research conclusion: under the condition of high temperature and high humidity three precooling measures all make the cyclist in power cycling sport ability improved, combination of oral ice slurry + ice vest precooling method to improve the sports ability of cyclist is superior to the separate use of oral ice slurry precooling measures, ice vest; precooling mechanism is characterized the core of lower body temperature, heart rate, blood flow perfusion index, increase body heat reserve capacity, but heat reserve capacity increases related to the influence of brain activity, neurohumoral factors, the cardiovascular and metabolic needs further research.
\end{abstract}

KEYWORD: High temperature and high humidity environment, power bicycle, ice vest, oral ice slurry, precooling

\section{INTRODUCTION}

With the development of modern technology, the Olympic Games have evolved for national scientific and technological strength of competition, the researchers of the emerging sports practice study the issue to ensure the ability to be able to maximize the movement of athletes. Since many events held in hot and humid environment, in t-his environment the performance of the reaction function of the body: the movement of early termination, resulting in fatigue, reduced exercise capacity, low thermal reserves, core temperature, the metabolic disorders physiological responses[4]. Many studies have shown that precooling before exercise is an effective way to reduce the body's temperature, increse the thermal reserve capacity and improve exercise capacity, precooling is a method widely used at present athletes for fatigue resistance due to high temperatures and humidity caused reduced exercise capacity. But what kinds of specific pre-cooling method is more co-nvenient and effective to improve athlete athleticability is still unclear[8]. Good Precooling mecha-nism to improve athletic ability can help coaches and sports scientists, athletes depend on different sports, different game environment choice the appropriate. 


\section{METHODS}

Participants

Twelve male Cyclists (mean \pm SD age $23.4 \pm 1.3 \mathrm{y}$, height $1.76 \pm 0.04 \mathrm{~cm}, \mathrm{BM} 73.6 \pm 2.6 \mathrm{~kg}$ ) were recruited as participants. Before the experiment strict medical screening to ensure the health of the subjects, with a good physique, to complete the requirements of the experiment.

Table 1 summary of participant characteristics

\begin{tabular}{|ll|}
\hline variable & \\
\hline Age & $23.4 \pm 1.3$ \\
Height $(\mathrm{m})$ & $1.76 \pm 0.04$ \\
Mass $(\mathrm{kg})$ & $73.6 \pm 2.6$ \\
\hline
\end{tabular}

\section{COOLING INTERVENTION}

Ice vests precooled $(\mathrm{J})$ precooling time is $30 \mathrm{~min}$.Oral ice slurry precooling (Ice) Total $8.1 \mathrm{~g} / \mathrm{kg}-1 \mathrm{BM}$ with $30 \mathrm{~min}, \quad 2.7 \mathrm{~g} / \mathrm{kg}-1 \mathrm{BM}$ every $10 \mathrm{~min}$, ice slurry temperature is $-1{ }^{\circ} \mathrm{C}$, the control group mineral water temperature $23{ }^{\circ} \mathrm{C}$. Joint precooling vest + ice ice slurry (J+Ice) using both pre-cooling methods $30 \mathrm{~min}$.oral ice slurry $8.1 \mathrm{~g} / \mathrm{kg}-1 \mathrm{BM}$ within $30 \mathrm{~min}$,
$2.7 \mathrm{~g} / \mathrm{kg}-1 \mathrm{BM}$ every $10 \mathrm{~min}$, ice slurry temperature is $-1{ }^{\circ} \mathrm{C}$. Control group mineral water temperature $23{ }^{\circ} \mathrm{C}$.

\section{EXERCISE PROTOCOL}

Subjects in hot and humid environment for power cycling increasing load. Movement starting load is $60 \mathrm{~W}$, every $5 \mathrm{~min}$ increase $40 \mathrm{~W}$, keep the movement speed of 60r / min, until the subjects prescribed speed exhaustive unsustainable, that the end of the experiment. Criteria exhaustion: When you reach a certain strength, maximal oxygen uptake does not increase heart rate, but the emergence of the platform; respiratory quotient $>1.10, \mathrm{HR}>180$ times / min, blood lactate $>7 \mathrm{mmol} / \mathrm{L}$; physical reach exhaustion, subjects ca-n not maintain the original velocity.

\section{STATISTICALANALYSIS}

Experimental data using statistical software spss 17.0t test, the results with the average standard deviation, statistical methods using Paired-Sample T Test, and $\mathrm{p}<0.05$ as statistically significant difference in the level of a very significant level of $\mathrm{p}<0.01$.

Table2 Effects of different precooling techniques on esercise distance of cyclists

\begin{tabular}{|c|c|c|c|c|c|}
\hline & & Mean distance $(\mathrm{m})$ & $\mathrm{N}$ & SD & Sig \\
\hline \multirow{2}{*}{ Group 1} & $\mathrm{C}$ & 3916.67 & 12 & 596.70 & \\
\hline & I & 4216.67 & 12 & 758.98 & 0.024 \\
\hline \multirow{2}{*}{ Group 2} & $\mathrm{C}$ & 3916.67 & 12 & 596.70 & \\
\hline & $\mathrm{J}$ & 4091.67 & 12 & 620.05 & 0.013 \\
\hline \multirow{2}{*}{ Group 3} & $\mathrm{C}$ & 3916.67 & 12 & 596.70 & \\
\hline & $\mathrm{J}+\mathrm{I}$ & 4525.00 & 12 & 696.07 & 0.000 \\
\hline \multirow{2}{*}{ Group 4} & $\mathrm{I}$ & 4216.67 & 12 & 758.98 & \\
\hline & $\mathrm{J}$ & 4091.67 & 12 & 620.05 & 0.382 \\
\hline \multirow{2}{*}{ Group 5} & $\mathrm{I}$ & 4216.67 & 12 & 758.98 & \\
\hline & $\mathrm{J}+\mathrm{I}$ & 4525.00 & 12 & 696.07 & 0.084 \\
\hline \multirow{2}{*}{ Group 6} & $\mathrm{~J}+\mathrm{I}$ & 4525.00 & 12 & 696.07 & \\
\hline & $\mathrm{J}$ & 4091.67 & 12 & 620.05 & 0.002 \\
\hline
\end{tabular}

** There were significant differences between conditons $(\mathrm{p}<0.01)$

* There were significant differences between conditons $(\mathrm{p}<0.05)$

Table 3 summary of the effects of Precooling on the body

\begin{tabular}{|c|c|c|c|c|c|c|c|c|}
\hline & \multicolumn{2}{|c|}{ C } & \multicolumn{2}{c|}{ I } & \multicolumn{2}{c|}{ J } & \multicolumn{2}{c|}{ J+I } \\
\hline & before & after & before & after & before & after & before & after \\
\hline Tc & $36 . .61 \pm 0.47$ & $36.57 \pm 0.45$ & $36.50 \pm 0.23$ & $36.15 \pm 0.35^{* *}$ & $36.61 \pm 0.18$ & $36.58 \pm 0.18$ & $36.45 \pm 0.22$ & $36.17 \pm 0.25^{* *}$ \\
\hline HR & $68.75 \pm 4.47$ & $68.75 \pm 4.47$ & $68.00 \pm 4.67$ & $62.67 \pm 5.83^{* *}$ & $66.92 \pm 5.08$ & $64.17 \pm 6.01$ & $69.92 \pm 4.92$ & $64.25 \pm 4.53^{* *}$ \\
\hline Tsk & $35.05 \pm 0.56$ & $34.92 \pm 0.49$ & $35.54 \pm 0.40$ & $35.62 \pm 0.33$ & $35.61 \pm 0.35$ & $34.99 \pm 0.60^{* *}$ & $35.16 \pm 0.86$ & $34.35 \pm 0.52^{* *}$ \\
\hline PI & $7 . .95 \pm 3.79$ & $6.23 \pm 1.88$ & $6.29 \pm 3.06$ & $3.37 \pm 1.85^{*}$ & $6.49 \pm 1.82$ & $5.3 \pm 2.15^{*}$ & $6.62 \pm 3.55$ & $3.80 \pm 2.07 *$ \\
\hline HB & $14.47 \pm 0.48$ & $14.30 \pm 0.51$ & $14.75 \pm 1.07$ & $14.42 \pm 0.9$ & $14.15 \pm 0.75$ & $13.96 \pm 0.72$ & $14.97 \pm 1.02$ & $14.68 \pm 0.90$ \\
\hline
\end{tabular}

Note: core(Tc);skin temperature(Tsk);heart rate(HR);perfusion index(PI);hemoglobin(Hb) ;control group(C),ice jacket group

$(\mathrm{J})$;ice slushy group $(\mathrm{I})$ and the combination of cooling group $(\mathrm{J}+\mathrm{I})$.

** There were significant differences between conditons $(\mathrm{p}<0.01)$

* There were significant differences between conditons $(\mathrm{p}<0.05)$ 


\section{RESULTS}

Table 2 illustrates the use of oral pre-cooling measures ice slurry compared with the control group, $(p<0.05)$ There was a significant difference; ice vest compared with the control group, $(\mathrm{p}<0.05)$ There Was a significant difference combined oral ice slurry+ice vest precooling, compared with the control group, $(p<0.05)$ there was a significant difference; compared ice vest pre-cooled with $(\mathrm{I}+\mathrm{J})(\mathrm{p}<0.01)$, there is a significant difference.

Table 3 oral ice slurry group core body temperature $(\mathrm{p}<0.01)$ before and after the pre-cooling has shown very significant difference; joint precooling the body's core temperature group $(\mathrm{p}<0.01)$ There was a significant difference; Joint precooling manner with respect to the single factor precooling measures can provide better precooling effect.

The effect of the precooling on athletes Heart Rate, As shown table 3, the heart rate $(\mathrm{p}<0.01)$ There was a significant difference between two groups before and after precooling, include oral ice slurry precooling and joint precooling group.

The effect of precooling on the surface temperature of athletes, in Table 3 the control group before and after the precooling the surface temperature significantly different; before and after pre-cooling the surface temperature of the ice vests group ( $\mathrm{p}<0.05$ ) were significantly difference.

Effect of precooling on athletes blood perfusion. In Table 3, perfusion index in the control group had no significant difference before and after the precooling; oral ice slurry, ice vests group, joint precooling group perfusion index $(\mathrm{p}<0.05)$ were significantly difference.

\section{CONCLUSION}

In hot and humid environment, oral ice slurry precooling, ice vest precooling, oral ice slurry + ice vest joint pre-cooling can improve exercise capacity cyclist. Oral ice slurry + ice vests combined effects than oral ice slurry, when used alone obviously precooling ice vest.

Mainly for precooling mechanism to reduce core body and skin temperature, increases the body's heat reserves, increase the heat storage capacity for brain activity, neurohormonal factors that affect the cardiovascular and metabolic pressed further studies are needed. After precooling the body's heart rate decreased induce perfusion index decreased. But whether precooling affect the central nervous system and improve the athlete's athletic ability still need to explore.

\section{REFERENCES}

[1] hsan M, Landers G, Brearley M, et al. Beneficial effects of ice ingestion as a precooling strategy on $40-\mathrm{km}$ cycling time-trial performance. Int $\mathrm{J}$ Sports Physiol Perform. 2010; 5(2):140-51.

[2] Quod MJ, Martin DT, Laursen PB, et al. Practical precooling: effect on cycling time trial performance in warm conditions. J Sports Sci. 2008; 26(14):1477-87.

[3] Thomas MM, Cheung SS, Elder GC, et al. Voluntary muscle activation is impaired by core temperature rather than local muscle temperature. J Appl Physiol. 2006; 100(4):1361-9.

[4] Marino FE. Methods, advantages, and limitations of body cooling for exercise performance. Br J Sports Med. 2002; 36(2):89-94.

[5] Hessemer V, Langusch D, Brück LK, Effect of slightly lowered body temperatures on endurance performance in humans. J Appl Physiol 1984 Dec; 57 (6): 1731-7.

[6] Marino FE. Methods, advantages, and limitations of body cooling for exercise performance. Br J Sports Med 2002 Apr; 36 (2): 89-94.

[7] Duffield R. Cooling interventions for the protection and recovery of exercise performance from exercise-induced heat stress. Med Sport Sei 2008; 53: 89-103.

[8] Scharhag-Rosenberger F, Meyer T, Gassier N. Exercise at given percentages of VO2max: heterogeneous metabolic responses between individuals. J Sei Med Sport 2010 Jan; 13(1); 74-9.

[9] Arngrimsson SA, Petitt DS, Stueck MG. Cooling vest worn during active warm-up improves $5-\mathrm{km}$ run performance in the heat. J Appl Physiol 2004 May; 96 (5):1867-74.

[10] Parsons K. Human thermal environments: the effects of hot, moderate, and cold environments on human health, com-fort and performance. Boca Raton (FL): CRC-Press, 2002.

[11] Laursen PB. Training for intense exercise performance: high-intensity or high-volume training? Scand J Med Sei Sports 2010 Oct; 20 Suppl. 2: 1-10.

[12] Cohen J. Statistical power analysis for the behavioral sciences. 2nd ed. Hillsdale (NJ): Erlbaum, 1988.

[13] Bergh U, Ekblom B. Physical performance and peak aerobic power at different body temperatures. J Appl Physiol 1979 May; 46 (5): 885-9. 